\title{
Reproductive dynamics of swordfish (Xiphias gladius) in the southwestern Indian Ocean (Reunion Island). Part 2: fecundity and spawning pattern
}

\author{
François Poisson ${ }^{1, \mathrm{a}}$ and Christian Fauvel $^{2}$ \\ 1 IFREMER, Centre de recherche halieutique méditerranéen et tropical, BP 171, av. Jean Monnet, 34203 Sète Cedex, France \\ 2 IFREMER, Laboratoire recherches aquacoles, Chemin de Maguelone, 34250 Palavas-les Flots, France
}

Received 19 December 2008; Accepted 11 March 2009

\begin{abstract}
Batch fecundity and relative fecundity of swordfish (Xiphias gladius) in the southwestern Indian Ocean were estimated from seven gravid swordfish females (size range 127-225 cm lower jaw-to-fork length, LJFL) with unovulated, hydrated oocytes collected onboard Reunion-based (France) longline swordfish fishing vessels between December 1999 to January 2001. To investigate the spawning pattern of swordfish, we used data collected through a combination of two at sea sampling regimes. A total of 17007 geo-located size data of swordfish were recorded during 8 years (1993-2001) and a total of 1727 (size range 75-289 cm, LJFL) swordfish gonads (1107 females and 620 males) were sampled from May 1998 to January 2001. The estimated batch fecundity ranged from 995000 hydrated oocytes for the smallest ripe female to 4.3 millions for the largest female sampled measuring respectively 127 to $225 \mathrm{~cm}$ in curved length (LJFL). The relative fecundity ranged from 25 to 72 hydrated oocytes per gram of body weight. We found that batch fecundity was positively correlated with fish length and that the older/larger females have earlier and longer spawning seasons than younger/ smaller females. These findings suggested that older/larger females which are seasonally migrating in this spawning ground seem to play a major role in reproductive success of the species in producing significantly more offspring than younger females during an extended spawning season. Examination of the length-frequency date from the fishery indicated that the young fish are resident around Reunion and around the seamounts off Reunion Island. Our results highlight the important role of the older/larger females in the reproductive capacity of southwestern Indian Ocean stock. We discuss the potential implications of fishing the older/larger females for this stock in terms of reproduction and recruitment.
\end{abstract}

Key words: Reproduction / Fecundity / Indian Ocean / Spawning frequency / Image processing / Gravimetric method / Reproductive strategy / Swordfish / Xiphias gladius

Résumé - Dynamique de la reproduction chez l'espadon (Xiphias gladius) du sud-ouest de l'océan Indien (île de La Réunion). Part 2 : Fécondité et mode de ponte. La fécondité par acte de ponte et la fécondité relative chez l'espadon (Xiphias gladius) dans le sud-ouest de l'océan Indien sont estimées d'après sept femelles de taille comprise entre 127 et $225 \mathrm{~cm}$ (de l'extrémité de la mâchoire inférieure à la fourche caudale); celles-ci ayant atteint la maturité sexuelle, les ovaires contenant des ovocytes hydratés. Ces femelles ont été pêchées entre décembre 1999 et janvier 2001, par des palangriers ciblant l'espadon et basés à La Réunion. La stratégie de la reproduction chez l'espadon a été étudiée en utilisant des données collectées au cours de deux campagnes d'échantillonnages en mer : soit 17007 mensurations géo-référencées d'espadons, de 75 à 289 cm, qui ont été enregistrées durant les 8 années d'étude (1993-2001) et 1727 gonades d'espadon (1107 femelles et 620 mâles) prélevées entre mai 1998 et juin 2001.La fécondité par acte de ponte estimée varie de 995000 ovocytes hydratés, pour la plus petite femelle $(127 \mathrm{~cm})$, à 4,3 millions pour la plus grande femelle $(225 \mathrm{~cm})$. La fécondité par acte de ponte est corrélée positivement à la taille du poisson. La fécondité relative s'étend de 25 à 72 ovocytes hydratés par gramme de poids de corps. Les femelles les plus âgées/grandes pondent plus tôt et sur une période plus grande que les plus jeunes/petites femelles. Ainsi, les femelles plus âgées/grandes qui migrent de façon saisonnière vers cette aire de ponte, contribueraient plus largement au renouvellement de l'espèce en produisant de façon significative davantage de recrues que les femelles plus jeunes et ceci pendant une saison de ponte plus étendue. Par ailleurs, les jeunes individus semblent séjourner aux abords de l'île de La Réunion et des monts sous-marins situés au large. Nos résultats soulignent l'importance du rôle des femelles âgées/grandes dans la capacité reproductrice du stock d'espadon du sud-ouest de l'océan Indien. Les implications potentielles de la pêche : des femelles âgées et de grandes tailles sont discutées pour ce stock, du point de vue de la reproduction et du recrutement.

a Corresponding author: Francois.Poisson@ifremer.fr 


\section{Introduction}

Swordfish (Xiphias gladius) is one of the most widely distributed pelagic fish species globally and makes up an important fishery resource in the entire Indian Ocean. The catches of swordfish markedly increased after 1990 to a peak of $35000 \mathrm{t}$ in 1998 (Anonymous 2008), and consequently the spawning stock biomass has decreased.

Swordfish reproductive biology has been investigated in other oceans (Pacific Ocean: Yabe et al. 1959; Shingu et al. 1974; Uchiyama and Shomura 1974; Miyabe and Bayliff 1987; DeMartini et al. 2001; Wang et al. 2003; Young et al. 2003; Atlantic Ocean: Taylor and Murphy 1992; Arocha and Lee 1995; Hazin et al. 2001, and in Mediterranean Sea: De la Serna et al. 1996). However, little is known about the reproduction of the swordfish population in Indian Ocean.

Putative spawning areas have been described (Mejuto et al. 2006) and some have been proposed based on the occurrence of spawning individuals and juveniles, on the occurrence of swordfish juveniles in the tunas and marlin stomach contents (Yabe et al. 1959), and on the occurrence of swordfish larvae in plankton tow samplings (Lütken 1880 in Palko et al. 1981; Bogorov and Rass 1961 (cited in Palko et al. 1981); Gorbunova 1969; Kondritskaya 1970; Nishikawa and Ueyanagi 1974).

In our first study, on reproductive dynamics of swordfish in the southwestern Indian Ocean (Poisson and Fauvel 2009), we assessed the reproductive activity using the macroscopic characteristics of the gonads, trends of gonadal indexes for both sexes, oocyte size frequency distributions and detailed histological examination, and finally in toto description of the development stages of the late oocytes after clearing fixation. We showed asynchronous oocyte development and confirmed that swordfish are multiple spawners. We demonstrated that a concurrent decrease of sea surface temperatures and an increase of the ratio of female can be an accurate proxy of the end of the spawning season in this area. We found that swordfish can spawn in the vicinity of Reunion Island during a protracted season of seven months when sea surface temperatures were above $24{ }^{\circ} \mathrm{C}$. At these temperatures, growth rates are assumed to be high, reducing consequently the time of the critical period of high mortality of larval and juvenile stages (Houde 1989; Dewees 1992; Young et al. 2003). We showed that spawning grounds of swordfish in the Indian Ocean and the eastern Pacific were localized in discrete areas. Finally, we found that swordfish exhibits size/sex synchronized movements between spawning grounds and neighboring regions.

Knowledge about reproduction is critically needed for the management and conservation of large pelagic fish (Medina et al. 2003; Corriero et al. 2002) and fluctuations in fecundity are an important component of reproductive variability (Kraus et al. 2000). However, no data have been published concerning these reproductive features of the population of the Indian Ocean while fisheries developed.

In this paper, we attempt to address the deficiency concerning swordfish reproduction data in the southwestern Indian Ocean, by first describing the cycle of oocyte production. We also investigate the individual fecundity of swordfish and compare those fecundity estimates with those published from other geographic areas. Finally, we identify the reproductive traits of the swordfish stock around Reunion Island and propose migration patterns to support management and conservation measures to ensure long-term sustainable yield.

\section{Materials and methods}

\subsection{Data sources}

To investigate the spawning pattern of swordfish, we used data collected through a combination of two at sea sampling regimes. Data from the following databases were extracted according to geographical and time strata and used in the size frequency distribution analyses.

\section{Geolocated size frequency database (database 1)}

A size monitoring program was designed to collect the lengths (and sex when possible) onboard domestic longliners. All the swordfish caught during each fishing operation covered were enumerated by trained observers. A total of 17007 geo-located size data of swordfish (4909 individuals with length and sex data; 12088 individual with length only) were recorded between January 1993 and January 2001 between $4^{\circ} \mathrm{S}$ and $32^{\circ} \mathrm{S}$ along with the information from fishing logbook (fishing locations, starting time of setting and retrieval, number of hooks deployed, number of fish caught by species, etc.).

\section{Swordfish reproduction database (database 2)}

For the purpose of the swordfish reproduction study, a total of 1727 swordfish samples (1107 females and 620 males) were collected from May 1998 to January 2001 between $19^{\circ}$ and $25^{\circ} \mathrm{S}$, and $48^{\circ}$ and $54^{\circ} \mathrm{E}$ onboard domestic longline vessels. For each fish, size and sex were assessed. The fishing techniques and method of samples collection have been described by Poisson and Fauvel (2009). Size data were included in the geo-located size frequency database (database 1).

\subsection{Fish samples}

The swordfish fecundity estimates were based on a sample of seven pre-spawning females covering a broad length range from 127 to $235 \mathrm{~cm}$ lower jaw-to-fork length (LJFL) sampled onboard domestic longline vessels from December 1999 to January 2001 (database 2). Females with unovulated, hydrated oocytes showing no evidence of current spawning (no hydrated eggs run under a moderate pressure on the gonads) were selected during the spawning season in January (1 individual), December (1 individual), February (3 individuals) and March (2 individuals). 


\subsection{Laboratory processing}

The weight of each whole ovary lobe was recorded to the nearest $5 \mathrm{~g}$ prior to any sectioning. Gonads were cut into right and left lobes. Then, oocytes were carefully stripped from the ovarian wall and also weighed to the nearest $5 \mathrm{~g}$.

The fecundity was estimated by the gravimetric method (Hunter et al. 1985). For each female, 30 "core sub-samples" ( 0.15 to $0.25 \mathrm{~g}$ ) of the most developed ovary lobe were taken randomly from the anterior, middle and posterior parts of one lobe. Each sub-sample was weighed with a precision of $0.01 \mathrm{~g}$ (Precisa, type XB 320 M).

The core samples were filtered twice to separate hydrated and non-hydrated oocytes using sieves of $1 \mathrm{~mm}$ and $0.5 \mathrm{~mm}$ mesh (Lowerre-Barbieri and Barbieri 1993). Hydrated oocytes were stained with Cochineal (E120) after a $10 \mathrm{~min}$ bath in the following medium: $3.5 \mathrm{~g}$ of Cochineal in $200 \mathrm{ml} 9 \%$ saline solution.

We used an image analysing system (Poisson and Fauvel 2009) to process each of the 30 sub-samples associated to each female. Hydrated oocytes were spread onto Petri dishes, photographed, and processed as grayscale images. Using the Visilog 5.1 (c) Program (Noesis, St. Aubin, France), image thresholds were set to define the outline of the egg, differentiating the background and foreground. At this point, each individual oocyte, as well as residual connective tissue, was counted as one object. A calibrated filter used a suite of measurements to characterize the size and shape of the objects to be included as oocytes and discarded objects that fell outside these parameters. A manual operation was performed to identify and eliminate remaining non-egg objects and subsequently deleted them from the count. Once all erroneous objects were excluded and checked, diameter measurements for each oocyte and total count of oocytes in the sub-sample were exported to an Excel(c) spreadsheet.

\subsection{Fecundity estimations and spawning frequency}

\section{Fecundity estimations}

The number of oocytes released per spawning or batch fecundity (BF) was estimated for each of seven females as the mean number of hydrated oocytes per gram found from the 30 subsamples multiplied by the total weight of the ovaries. Relative fecundity (RF), the number of hydrated oocytes per gram round body weight, was calculated by dividing BF by the estimated individual round weight. The relationships of batch fecundity to the round weight was described using standard regression analysis.

\section{Spawning frequency}

Spawning frequency was estimated according to the "hydrated oocyte assessment" developed by Hunter and Macewicz (1985) and used by Arocha and Lee (1996) and Young et al. (2003) to determine the swordfish spawning frequency during the spawning season in northern Atlantic and off eastern Australia respectively. The gonadal index developed for swordfish females by Hinton et al. (1997) was found suitable for individuals caught in Reunion Island waters (Poisson and Fauvel 2009). Therefore for each month of the spawning season (October to April), females with a gonadal index (GI) higher or equal to the threshold value 1.375 , were considered reproductively active (Es) according to Hinton et al. (1997). Of the reproductively active females, we considered that the females with hydrated oocytes present in their ovaries were spawning females (Ep). The average percentage of spawning females was estimated applying the following formulas:

$$
P f=\frac{1}{m} \sum_{i=1}^{m}\left(\frac{E \mathrm{p}_{i}}{E \mathrm{~s}_{i}} \times 100\right) .
$$

Where:

$E p=$ number of pre-spawning females (with hydrated oocytes in their ovaries).

$E s=$ number of females reproductively active

$m=$ duration of the spawning season; number of months And for the spawning frequency

$$
S f=1 / P f .
$$

An important underlying assumption inherent to this approach is that the distribution pattern of the spawning stock is unchanged during the reproduction season.

\section{Results}

\subsection{Length composition of the catch}

The average lengths of swordfish, both sexes pooled, varied with months. The average LJFL increased dramatically after August to peak at $168 \mathrm{~cm}(S D=29 \mathrm{~cm})$ in October, a slight decrease was noticed in November. After January, the values rose again to level off until May (at around $159 \mathrm{~cm}$ ). The values are the lowest during the non-spawning season from June to August (around $154 \mathrm{~cm}$ ) (Fig. 1).

The monthly size frequency of swordfish, both sexes pooled, caught by the domestic fleet between $19^{\circ}$ and $25^{\circ} \mathrm{S}$ and $48^{\circ}$ and $54^{\circ} \mathrm{E}$, showed a significant percentage of fish having length smaller than $100 \mathrm{~cm}$ LJFL, in March and in April (Fig. 2, arrows).

The population of swordfish also showed a latitude dependent structure since the mean lengths of fish caught in the following areas (Area $1 ;<15^{\circ} \mathrm{S}$, Area 2; between $15^{\circ} \mathrm{S}$ and $25^{\circ} \mathrm{S}$; Area $3 \geqslant 25^{\circ} \mathrm{S}$ ) were significantly different and exhibited a positive gradient from North to South (Fig. 3). Swordfish average lengths (LJFL) were respectively $144 \mathrm{~cm}(S D=30 \mathrm{~cm})$, $159 \mathrm{~cm}(S D=29), 172 \mathrm{~cm}(S D=28)$ in area 1,2 and 3 (Fig. 3).

\subsection{Length distribution in relation to sex and reproductive activity period}

Within each sex, the size range of sampled fish did not differ between spawning and sexual rest periods and ranged between 75 and $245 \mathrm{~cm}$ LJFL for females and 75 and $220 \mathrm{~cm}$ 


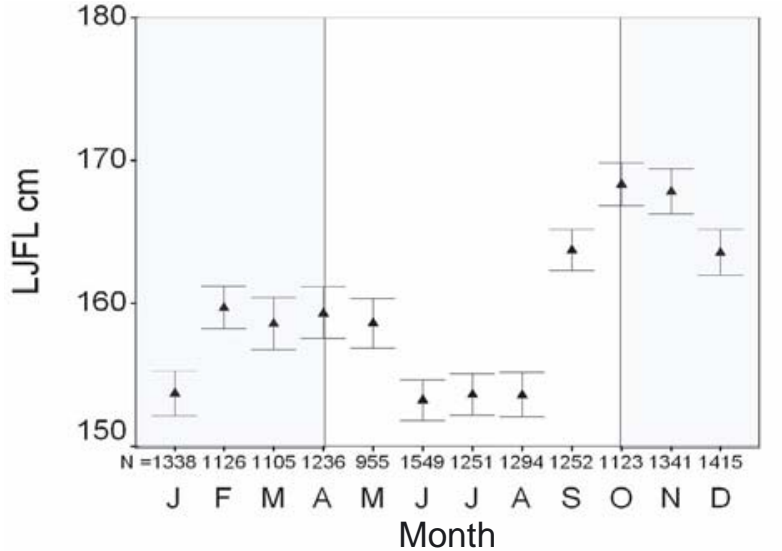

Fig. 1. Mean body lengths (LJFL, cm) and associated 95\% CI of swordfish (Xiphias gladius), both sexes combined by month caught by the Reunion-based longline fishery between January 1993 and January 2001 ( $n=14985$ individuals) on the spawning ground, between $19^{\circ}$ and $25^{\circ} \mathrm{S}$ and $48^{\circ}$ and $54^{\circ} \mathrm{E}$. Shaded areas show the spawning season period between October and April.

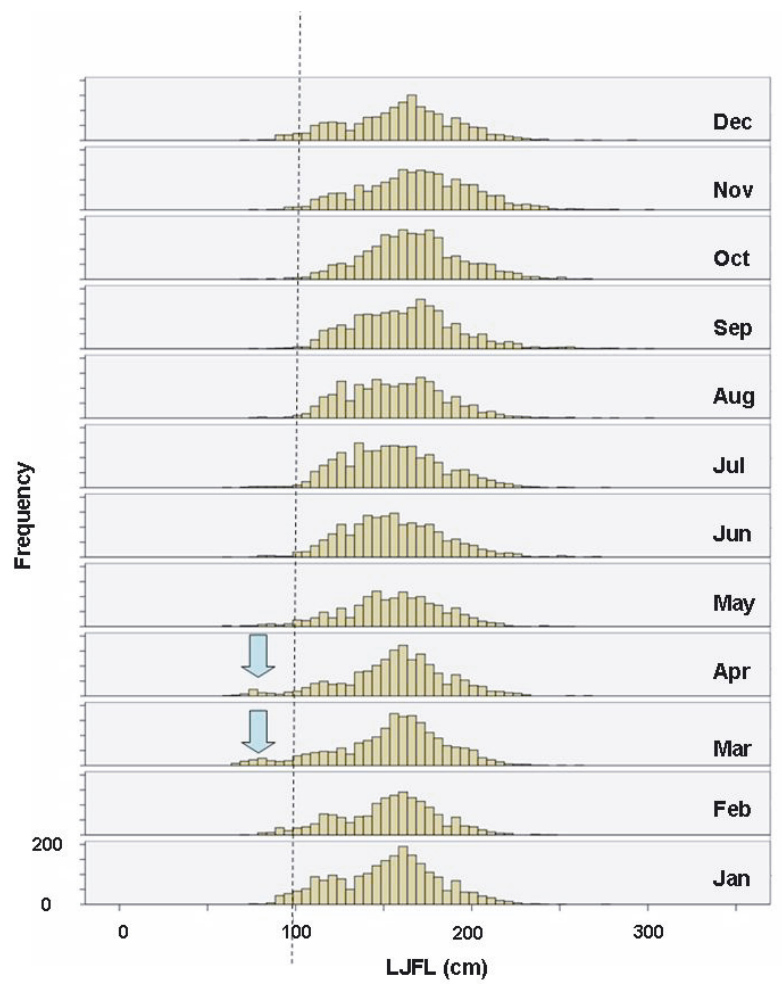

Fig. 2. Size of swordfish (Xiphias gladius) both sexes pooled sampled between January 1993 and January 2001 on the spawning ground (between $19^{\circ}$ and $25^{\circ} \mathrm{S}$ and $48^{\circ}$ and $54^{\circ} \mathrm{E}$ ) combined by month.

LJFL for males. However, the distribution of length of swordfish caught by longliners differed as a function of sex and season. There was a significant difference in the size distribution (Fig. 4) of fish caught during the spawning season (October to April) versus the non spawning season (May to November) for females (Kolmogoroff-Smirnoff $(\mathrm{K}-\mathrm{S})$ test, $p<0.0001)$ and for males (K-S test, $p<0.0001)$.

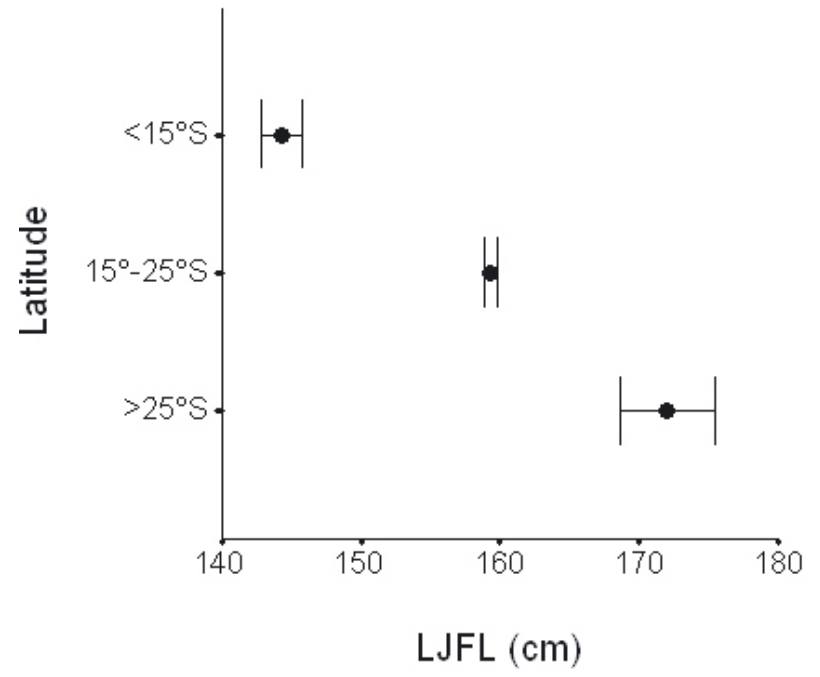

Fig. 3. Mean body length (LJFL, cm) and associated 95\% CI of swordfish (Xiphias gladius) both sexes combined by latitude class, caught by the Reunion-based longline fishery between January 1993 and January 2001 ( $n=17007$ individuals).

For males, the distribution is centered around $150 \mathrm{~cm} \mathrm{LJFL}$ during sexual rest and showed a negative skewness during reproductive season (mode $185 \mathrm{~cm}$ ) whereas for females, length showed a positively skewed distribution (mode: $155 \mathrm{~cm} \mathrm{LJFL)}$ during sexual rest and a bimodal distribution during sexual activity, 130 and $195 \mathrm{~cm}$ LJFL.

\subsection{Characterisation of reproductive activity}

The gonadal index (GI) of females varied on a yearly basis with highest values in summer and lowest ones in winter (austral seasons). However, these variations differ with female size and we could identify the groups with different GI patterns: large females (LJFL > $190 \mathrm{~cm}$ ), medium (between 150 and $190 \mathrm{~cm} \mathrm{LJFL}$ ) and small (LJFL $<150 \mathrm{~cm}$ ).

The GI values for the larger females increased after September to peak at around 1.5 until December, a slight decrease was noticed in January. The values rose again to level off around 1.5 in February and March before decreasing gradually and bottoming-out at 1.2 during three months. A similar pattern was found for the medium females from January to September but GI increased slightly thereafter compared to that of large females and did not exceed the threshold value proposed by Hinton to describe sexually active females. In smaller size class females, GI remained below 1 and showed low variations compared to the other size classes.

Thus, older/larger females had a protracted reproductive period of seven months (October to April) while reproductive period of smaller fish (between 150 and $190 \mathrm{~cm}$ LJFL) appeared to be reduced to two months (February-March) suggesting that spawning activity did not include the same fractions of population throughout the period (Fig. 5). 

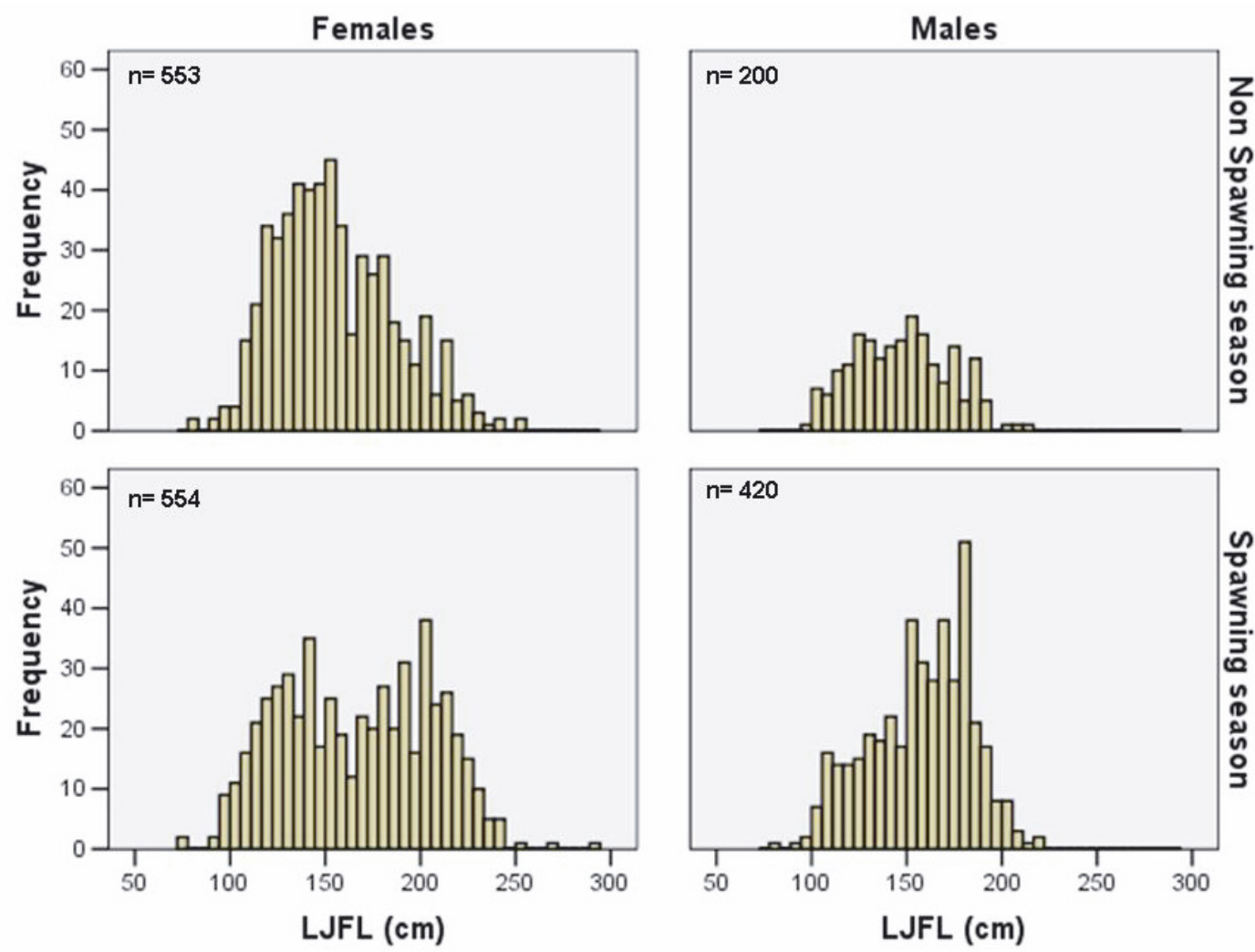

Fig. 4. Size distribution of swordfish per sex sampled during the spawning season (October to April) and non spawning season (May to November).

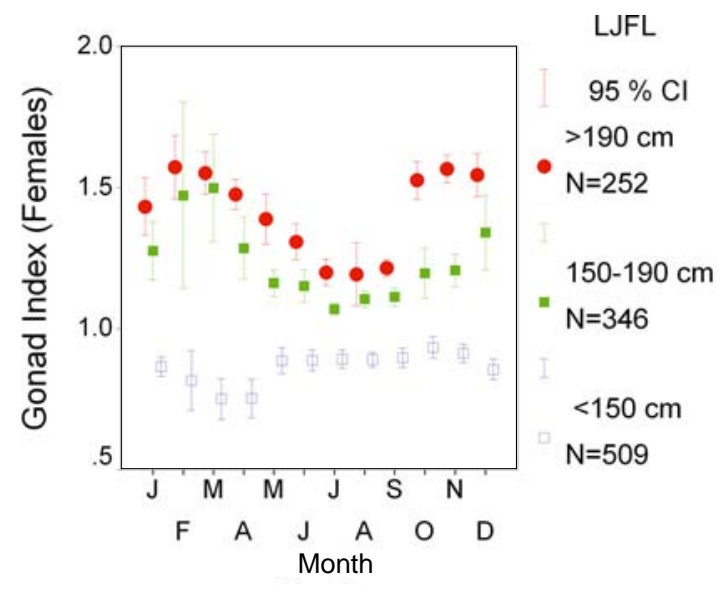

Fig. 5. Monthly variation of mean gonad index of female swordfish related to 3 size classes (LJFL $<150 \mathrm{~cm}, 150<\mathrm{LJFL}<190 \mathrm{~cm}$, LJFL $>190 \mathrm{~cm}$ ) in the vicinity of Reunion Island. Vertical bars are 95\% confidence intervals. The threshold value (1.375) of the gonad index defined by Hinton et al. (1997) above which females should spawn shortly (reproductively active).

\subsection{Batch fecundity (BF)}

We observed from 337 to 518 hydrated oocytes per gram of ovary with reduced confidence intervals of the mean within ovaries.
The estimated BF of the females examined during the study ranged from $994 \pm 20 \times 10^{3}$ hydrated oocytes for the smallest ripe female measured ( $127 \mathrm{~cm} \mathrm{LJFL)} \mathrm{to} 4323 \pm 180 \times$ $10^{3}$ for the largest female sampled (225 cm LJFL) (Table 1). $B F$ (in million oocytes) was correlated with the length (LJFL) with the relationship best described by the linear regression. $B F=0.024 \mathrm{LJFL}-1.293\left(r^{2}=0.661 ; F=12.676 ; d f=1.5\right)$ (Fig. 6).

\subsection{Relative fecundity (RF)}

The RF decreased from 72 to 25 hydrated oocytes/g body weight with the theoretical round weight (RW in kg from LJFL values). The weight of ovarian wall tissue ranged between 270 and $500 \mathrm{~g}$, represented 3 to $14 \%$ of total ovary weight (Table 1), and was not related to female weight.

\subsection{Spawning frequency}

The average percentage of spawning females (exhibiting hydrated oocytes) within sampling during the seven months of the spawning season was $36 \%$ (Table 2), giving a theoretical mean spawning interval of 2.77 days. Thus, a ripe female could have spawned about 76 times during the 212 days of the main reproductive season.

Based on the monthly trend of the proportion of ripe females, spawning peaks occurred in November-December, and 
Table 1. Individual data used for batch fecundity $(B F)$ and relative fecundity $(R F)$ estimates of seven ripe female swordfish collected in the vicinity of Reunion Island. The data include information on the month of capture, lower jaw-to-fork length ( $L J F L)$, eye-to-fork length $(E F L)$, round weight, gonadal index $(G I)$, total weight of oocytes and whole gonad weight. The body length was converted into round weight $(R W)$ by the following equation: $R W=1.33 \times\left(5.864 \times 10^{-6} \times \mathrm{LJFL}^{3.0849}\right)$ (Poisson et al. 2001).

\begin{tabular}{|c|c|c|c|c|c|c|c|c|c|c|c|}
\hline Month & $\begin{array}{l}L J F L \\
(\mathrm{~cm})\end{array}$ & $\begin{array}{l}E F L \\
(\mathrm{~cm})\end{array}$ & $\begin{array}{l}\text { Round } \\
\text { weight } \\
\text { (kg) }\end{array}$ & $\begin{array}{c}B F \\
\left(\times 10^{3)}\right.\end{array}$ & $\begin{array}{c}\text { Average of } \\
\text { hydrated } \\
\text { oocytes/g } \\
\text { ovaries } \\
\text { weight (95\% } \\
\text { CI) }\end{array}$ & $R F$ & GI & $\begin{array}{c}\text { Whole } \\
\text { gonad } \\
\text { weight } \\
(\mathrm{g})\end{array}$ & $\begin{array}{c}\text { Oocytes } \\
\text { total } \\
\text { weight } \\
(\mathrm{g})\end{array}$ & $\begin{array}{l}\text { Gonad } \\
\text { wall } \\
\text { weight } \\
(\mathrm{g})\end{array}$ & $\begin{array}{c}\text { Gonad } \\
\text { wall }\end{array}$ \\
\hline February & 127 & 109 & 24 & $9940 \pm 20$ & $518 \pm 13$ & 41.4 & 1.61 & 1920 & 1650 & 270 & 14.1 \\
\hline January & 192 & 170 & 86 & $2769 \pm 160$ & $373 \pm 12$ & 32.2 & 1.73 & 7425 & 6940 & 485 & 6.5 \\
\hline February & 155 & 135 & 44 & $2883 \pm 170$ & $338 \pm 14$ & 65.5 & 1.85 & 8530 & 8040 & 490 & 5.7 \\
\hline March & 157 & 137 & 46 & $3300 \pm 130$ & $404 \pm 16$ & 71.8 & 1.83 & 8170 & 7670 & 500 & 6.1 \\
\hline February & 198 & 176 & 95 & $3990 \pm 120$ & $408 \pm 20$ & 42.0 & 1.78 & 9780 & 9370 & 410 & 4.2 \\
\hline December* & 235 & 211 & 160 & $4016 \pm 120$ & $459 \pm 22$ & 25.1 & 1.7 & 8750 & 8270 & 480 & 5.5 \\
\hline March & 225 & 201 & 141 & $4323 \pm 180$ & $337 \pm 14$ & 30.7 & 1.78 & 12830 & 12440 & 390 & 3.0 \\
\hline
\end{tabular}

*This gonad was frozen prior laboratory processing.

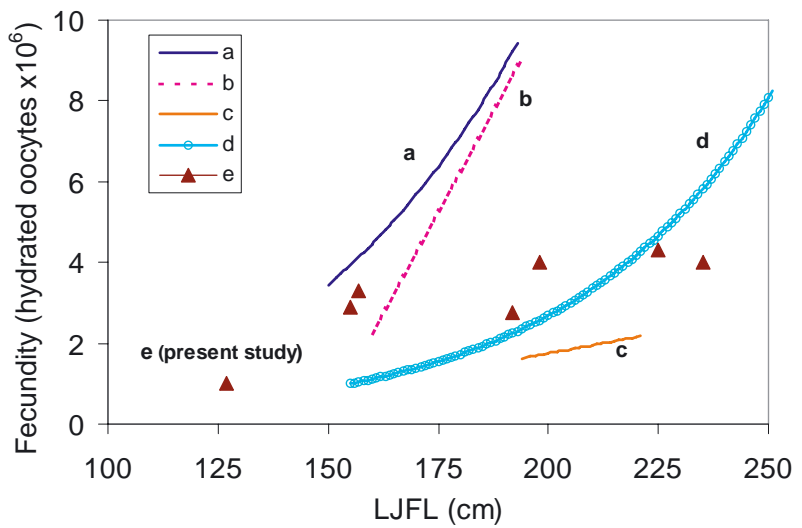

Fig. 6. Batch fecundity (number of hydrated oocytes $\times 10^{6}$ ) estimates in relation to body length, $\mathrm{BF}=0.024 \mathrm{LJFL}-1.293\left(r^{2}=0.661\right)$. Other estimates in different swoordfish stocks are plotted for comparison (a) Mediterranean Sea (De la Serna et al. 1996), (b) Atlantic Ocean (Hazin et al. 2001), (c) Pacific Ocean (Young et al. 2003), (d) Atlantic Ocean (Arocha 2007), (e) Indian Ocean (present study).

in February then the reproductive activity decreased. Almost $20 \%$ of mature females were ripe in April at the end of the spawning season (Table 2).

\section{Discussion}

Fecundity estimates are based on specimens with hydrated oocytes in the ovaries, which indicate imminent spawning. All the fish caught by the domestic fleet were gutted onboard and landed dressed. Therefore, samples were collected at sea onboard commercial boats but the occurrence of swordfish exhibiting these physiological conditions during these trips was rather limited. Therefore, our fecundity estimates derived from a sample of 7 specimens. However, sample sizes in other studies were generally small $(<=10)$ except for Arocha (2007) study based on 29 specimens who conducted his research over
Table 2. Number of reproductively active females (Es) and percentage of ovulating swordfish females (OSF) with spawning process triggered, during the main spawning season (October-April) from two consecutive entire spawning periods, between May 1998 and January 2001.

\begin{tabular}{lccc}
\hline Month & Es & $\begin{array}{c}\text { Number of } \\
\text { females } \\
\text { with hydrated } \\
\text { oocytes }\end{array}$ & $\%$ OSF \\
\hline October & 31 & 12 & 39 \\
November & 46 & 21 & 46 \\
December & 32 & 16 & 50 \\
January & 14 & 4 & 29 \\
February & 10 & 4 & 40 \\
March & 20 & 6 & 30 \\
April & 31 & 6 & 19 \\
\hline Total & 184 & 69 & \\
\hline
\end{tabular}

5 years (Table 3 ). This reflects the difficulty to collect accurate individuals from commercial fishery samples.

\subsection{Gravimetric Method - Image processing and measurement of oocytes}

The gravimetric method is generally used to estimate batch fecundity of the swordfish. Brilliant red colour derived from cochineal (E-120) soaking medium contrasted well hydrated oocytes edges and tremendously improved the quality of the images to be analysed. Automated image analysis, accurate staining and manual elimination of debris in the image field also proved to be highly effective. Standardized and straightforward imaging-based technique to count and measure batches of oocytes allowed us to process a large number of subsamples in a limited time. The utility of image analyses systems (IAS) approach was already assessed when studying fish reproduction (Nielson et al. 1993; Mc Carthy et al. 2008). 
Table 3. Estimates of relative batch fecundity and batch fecundity estimates, reported by different authors about reproductive dynamics of swordfish in different areas.

\begin{tabular}{|c|c|c|c|c|c|c|c|}
\hline Area & Authors & $\begin{array}{l}\text { Relative Batch } \\
\text { fecundity } \\
\text { estimates } \\
\text { Oocyte/g body } \\
\text { weight (mean) } \\
\end{array}$ & $\begin{array}{c}\text { No subsamples } \\
\text { (sample size range) }\end{array}$ & Sample size & $\begin{array}{c}\text { Batch } \\
\text { fecundity } \\
\text { estimates }\end{array}$ & $\begin{array}{l}L J F L \\
(\mathrm{~cm})\end{array}$ & $\begin{array}{l}\text { Weight } \\
\text { (kg) }\end{array}$ \\
\hline Indian Ocean & Present study & $25.1-71.8(44.1)$ & $\begin{array}{c}30 \\
(100-200 \text { oocytes }) \\
\end{array}$ & 7 & $\begin{array}{l}9000 \times 10^{3} \\
4300 \times 10^{3} \\
\end{array}$ & $\begin{array}{l}127 \\
225 \\
\end{array}$ & $\begin{array}{c}24 \\
141\end{array}$ \\
\hline Pacific Ocean & $\begin{array}{l}\text { North East } \\
\text { Uchiyama and Shomura } \\
\text { (1974) }\end{array}$ & $12-65.9(34)$ & $\begin{array}{c}1 \\
\text { (113-403 oocytes) }\end{array}$ & 8 & $\begin{array}{l}3210 \times 10^{3} \\
6200 \times 10^{3}\end{array}$ & - & $\begin{array}{c}83 \\
204\end{array}$ \\
\hline & $\begin{array}{l}\text { South East } \\
\text { Young et al. (2003) }\end{array}$ & $8.7-13.9(11.9)$ & $\begin{array}{c}6 \\
(1-4 g)\end{array}$ & 9 & $\begin{array}{l}1180 \times 10^{3} \\
2500 \times 10^{3} \\
\end{array}$ & $\begin{array}{l}193 \\
239 \\
\end{array}$ & - \\
\hline Atlantic Ocean & $\begin{array}{l}\text { North West } \\
\text { Arocha (2007) } \\
\text { Strait of Florida } \\
\text { Taylor and Murphy (1992) } \\
\text { Southwest Equatorial } \\
\text { Hazin et al. (2001) }\end{array}$ & $\begin{array}{c}13.3-61.6(30.6) \\
12.6-44.9(21.3) \\
41.1-106.6 \\
(76.4) \\
\end{array}$ & $\begin{array}{c}3 \\
1 \\
(2-3 \mathrm{~g}) \\
15 \\
(0.8-1.0 \mathrm{~g})\end{array}$ & $\begin{array}{l}29 \\
7 \\
10\end{array}$ & $\begin{array}{l}990 \times 10^{3} \\
990 \times 10^{3} \\
1400 \times 10^{3} \\
4200 \times 10^{3} \\
2000 \times 10^{3} \\
8600 \times 10^{3}\end{array}$ & $\begin{array}{l}166 \\
245 \\
177 \\
281 \\
160 \\
194\end{array}$ & $\begin{array}{c}- \\
- \\
69 \\
268 \\
- \\
-\end{array}$ \\
\hline $\begin{array}{l}\text { Mediterranean Sea } \\
\text { Sea }\end{array}$ & $\begin{array}{l}\text { De la Serna et al. } \\
\text { (1996) }\end{array}$ & $50.8-150.6(104.3)$ & ? & 16 & $\begin{array}{l}2100 \times 10^{3} \\
9900 \times 10^{3}\end{array}$ & $\begin{array}{l}151 \\
182\end{array}$ & $\begin{array}{l}39 \\
70\end{array}$ \\
\hline
\end{tabular}

\subsection{Batch fecundity}

We showed that swordfish batch fecundity in southwest Indian Ocean increased with the size of the females as it is the case for other studies. A distinctive feature of our study is that one individual sampled (a $24 \mathrm{~kg}$ female) consisted of the smallest swordfish specimen ever studied for fecundity (Table 3). The batch fecundity estimates in the present study were similar to those reported in the strait of Florida (Taylor and Murphy 1992), but lower than what has been reported in the Mediterranean (De la Serna et al. 1996), in the North Pacific (Uchiyama and Shomura 1974) and in the Atlantic (Arocha and Lee 1996; Hazin et al. 2001). The latter are the highest recorded in the literature, ranging respectively between 2-8.6 million and 2.1-9.9 million eggs per spawn. The lowest $\mathrm{BF}$ estimates were recorded by Young et al. 2003 in the Pacific off the east coast of Australia (1.18-2.5 million eggs per spawn). The combination of all the data available highlights the variability of the BF estimates among studies (Table 3).

\subsection{Variability in fecundity estimates}

The discrepancy in BF estimates reported, within or among the various studies, is the result of one or a combination of factors including the choice of the biological material, the sample sizes and the methods employed at the different levels of the estimation process.

An overview of the literature shows that the fecundity of individual female swordfish of the same size within the same study can present considerable deviations.

The timing of ovary collections of serial spawners like swordfish may introduce bias and variation of batch fecundity could be expected because the portion of recruited and ovulated eggs fluctuates as the spawning season progresses (Arocha et al. 1994).

The range of fish size/age selected, the duration of the sampling scheme over one or during consecutive spawning seasons as well as the fish sample sizes are important parameters which could impact the fecundity estimates for a stock. Spatial and temporal variations in stock structure and environmental conditions may also affect the fecundity estimates, besides the fact that stock fecundity may also dramatically vary annually (Hunter et al. 1985; Horwood et al. 1986).

We showed that the fecundity assessment methods are variable. Thus, Young et al. (2003) counted strictly hydrated oocytes using the method described by Schaefer (1996), whereas other authors considering only the oocyte diameters, might have selected advanced yolked oocytes and above. Since we found that the ovarian wall can account for 3 to $14 \%$ of the ovary weight, there may be some concerns about the estimates of fecundity based only on ovary weight.

\subsection{Relative batch fecundity}

In the current study, the maximum relative batch fecundity estimates were lower than those reported for the Atlantic population (Hazin et al. 2001) and those reported in the Mediterranean sea (De la Serna et al. 1996), but similar to those reported by Uchiyama and Shomura (1974) and Arocha et Lee (1996). These estimates allowed us to gauge the fecundity of the swordfish among tunalike species. Though, swordfish batch fecundity estimates were similar to that found in southern bluefin tuna (Thunnus maccoyii) (57 oocytes per gram of body weight) (Farley and Davis 1998) and to yellowfin tuna (Thunnus albacares) (54.7 to 63.5 oocytes per gram of body weight) (Itano 2000) but lesser than for black skipjack 
(Euthynnus lineatus) (Schaefer 1987) and skipjack (Katsuwonus pelamis) (100 to 148 oocytes per gram of body weight) (Stéquert and Ramcharrun 1995; Cayré and Farrugio 1996; Ashida et al. 2008).

\subsection{Reproductive strategy}

The results of the current study emphasise key points of the reproductive strategy of the swordfish population in the vicinity of Reunion Island. We previously showed that the spawning season starts in early October with the arrival of older, larger individuals and lasts until April and we confirmed that swordfish produce several successive oocyte batches (Poisson and Fauvel 2009). Nevertheless, it is unlikely that an individual female would spawn throughout this entire period of time. The long spawning season may result from a turn over of new spawners replacing individuals on the spawning ground throughout the season. Even if the theoretical mean spawning interval estimated ( 2.8 days between October to April) was similar to that found by Arocha and Lee (1996) (2.3 days) and by Young et al. (2003) (3.0 days), this hypothesis should be taken cautiously in southwestern Indian Ocean. Several lines of evidence support this assumption including:

(1) observed fluctuations in the monthly size composition throughout the spawning season, (2) identification of different seasonal spawning peaks, (3) the variability in the percentage of spawning females in the season and (4) variations in the duration of spawning periods depending on female fish size. Similar pattern of spawning per age/size group variations has been already suspected by Young et al. (2003).

Consequently, individuals may spawn for a short period of time which does not cover the entire spawning period and the annual fecundity, so that the sum of batch fecundities per age/size group, may be de facto, much lesser than generally assumed. This finding constitutes an important reproductive trait of the swordfish stock in the vicinity of Reunion Island. Moreover, based on the length distribution of the swordfish captured, we hypothesized that different size swordfish mingle in this area and that larger individuals might migrate into and out of the region, whereas smaller individuals may remain in about the same latitudes, favouring the mixing of individuals from different generations which is also one of the important factors of stock reproductive potential of a population (Cardinale and Arrhenius 2000).

We previously indicated that spawning activity is located in discrete areas in the South western Indian Ocean (Poisson and Fauvel 2009). Reunion Island waters seem to provide appropriate environmental conditions for spawning over a seven months protracted season and for growth of the larvae and juveniles. This could be insured the reproductive success of swordfish Reunion Island latitudes as spawning season duration increases the survival probability of offspring (Lambert and Ware 1984).

Finally, some individuals ranging from 70 to $85 \mathrm{~cm}$ LJFL were caught incidentally (these undersized fish were not expected due to the size of the bait and the hook), by the fleet on the fishing ground mainly in March and April. Some other small specimens were also retrieved in dolphin fish and marlin stomachs These individuals could correspond to young of the year fish of both sexes which hatched at the beginning of the spawning season (Sun et al. 2002); according to De Martini et al. (2007), male and female swordfish clearly grow in length at different rates after age 1 , male and female at 0.58 year old are respectively; $82.1 \mathrm{~cm}$ EFL and $82.3 \mathrm{~cm}$ EFL (around $96 \mathrm{~cm}$ LJFL). Young-of-the-year (YOY) juvenile swordfish, devoting most of the energy to growth, are likely to remain at the same latitudes and increase the youngest cohorts the following months. Thus, a strong "residency behaviour" of the young fish in the region is suspected which is consistent with observations of sub-population localised around particular oceanic features like sea mounts and Islands (Sedberry and Loefer 2001) and the concept of the "viscosity" of the swordfish resource (Campbell 2002).

\subsection{Implications for management and future research needs}

Older/bigger females which are seasonally migrating seem to play a major role in reproductive success of the species by producing significantly more offspring than younger females during an extended spawning season.

Swordfish stock under a high fishing pressure for decades in this part of the world may be affected by the phenomenon called "size and age structure truncation" which could induce decline in age and length at maturity and finally lower population productivity (Conover and Munch 2002).

Moreover, Berkeley et al. (2004), Longhurst (2002) proposed the Big old fat fecund female fish (BOFFFF) hypothesis suggesting that these individuals are more biologically valuable due to their age and reproductive abilities.

If this hypothesis is confirmed for swordfish, the removal of the larger, older individuals could be detrimental for this stock and the current results should be used to support new policies to preserve population age structure and to allow escapement of unwanted sized fish.

Neilson et al. (unpublished) using data from archival tagging operations conducted in Canadian waters confirmed the homing pattern observed in Pacific Ocean (Takahashi et al. 2003) and hypothesized that swordfish formed, in the northwest Atlantic swordfish a metapopulation.

Therefore, additional research is required (1) to accurately assess fecundity parameters and (2) to demonstrate evidence for spawning and feeding site fidelity of swordfish in Indian Ocean. More sampling is also needed to evaluate the intraand inter-annual spatial and temporal variability in reproductive capacity in order to incorporate annual egg production estimates into Indian Ocean swordfish stock assessments.

\section{Conclusion}

This study contributes to a better understanding of the reproductive dynamics of swordfish population in the southwestern Indian Ocean. We implemented an efficient method to measure oocytes diameters of a large number of subsamples in a limited time, based on an accurate staining process and automated image analysis. First fecundity estimates were presented 
and we showed that variability in batch fecundity estimates reported in the various published studies results from one or a combination of the factors related to sampling regime, to the methodology, and to the stock studied.

The key points of the reproductive strategy of the swordfish population in the vicinity of Reunion were characterized and identified. Thus, older, larger females have earlier and longer spawning seasons (from October to December and January to April) than younger, smaller females (February-March). Moreover, based on the distribution of the swordfish captured, we hypothesized that different size swordfish mingle in this area and that larger individuals might migrate into and out of the region, whereas smaller individuals may remain in about the same latitudes, favouring the mixing of individuals from different generations. We found that Reunion Island waters exhibit the appropriate environmental conditions for adults to spawn over a protracted season allowing growth of the larvae and juveniles during seven months. We also suspected that the younger fish in our study tend to remain at these latitudes. Our results outlined the important role of the older/larger in the reproductive capacity of the population and as a consequence, the swordfish population could be negatively affected if the new hypotheses on maternal effects and genetic diversity would apply to the species. The results of additional research on swordfish reproduction and associated migration patterns could be used to support management and conservation measures designed to maintain or improve the swordfish stocks.

Acknowledgements. The "Programme Palangre Réunion" (PPR) project was an IFREMER programme financed by the European Union (FEDER), Conseil Régional and Conseil Général de La Réunion. This Project would not have been possible without the support of the Reunion Island longline fishery. We would like to express our gratitude to the skippers who have voluntary allowed scientific observers on board vessels and to all people involved in the sampling. We thank Mike Laurs and Freddy Arocha for reviewing earlier versions of this manuscript and providing helpful advices and suggestions. We extend our gratitude to anonymous referees for helpful comments on the manuscript. Our thanks go also to Pierre Lopez for his inputs into the improvement of the illustrations of this paper.

\section{References}

Anonymous, 2008, Status of IOTC databases for billfish species. Sixth Session of the IOTC Working Party on Billfish Seychelles 7-11 July 2008. IOTC-2008-WPB-08.

Arocha F., 2007, Swordfish reproduction in the Atlantic Ocean: An overview. Gulf Caribb. Res. 19, 21-36.

Arocha F., Barrios A., 2009, Sex ratios, spawning seasonality, sexual maturity, and fecundity of white marlin (Tetrapturus albidus) from the western central Atlantic. Fish. Res. 95, 98-111.

Arocha F., Lee D.W., 1996, Maturity at size, reproductive seasonality, spawning frequency, fecundity and sex ratio in the swordfish from the Northwest Atlantic. Int. Comm. Conserv. Atl. Tunas Coll. Vol. Sci. Pap. 45, 350-357.

Arocha F., Lee D.W., Grubich J.R., 1994, Observations on sex ratio, maturity stages, and fecundity estimates of swordfish, Xiphias gladius, in the Northwest Atlantic Ocean. Int. Comm. Conserv. Atl. Tunas, Coll. Vol. Sci. Pap. 42, 309-318.
Ashida H., Tanabe T., Suzuki N., Fukui A. Tanaka S., 2008, Spawning frequency and batch fecundity of skipjack tuna Katsuwonus pelamis in the tropical west-central Pacific Ocean. Nippon Suisan Gakkaishi 74, 802-808.

Berkeley S.A., Chapman C., Sogard S., 2004, "Maternal age as a determinant of larval growth and survival in a marine fish, Sebastes melanops". Ecology 85, 1258-1264.

Campbell R., 2002, Sequential changes in swordfish catch rates off eastern Australia and possible implications for the movement dynamics of the local swordfish population. Working paper BBRG9, 15th meeting of the Standing Committee on Tuna and Billfish, 21-26 July 2002, Honolulu.

Conover D.O., Munch S.B., 2002, Sustaining fisheries yields over evolutionary time scales. Science 297, 94-96.

Cardinale M., Arrhenius F., 2000, The influence of stock structure and environmental conditions on the recruitment process of Baltic cod estimated using a generalized additive model. Can. J. Fish. Aquat. Sci. 57, 2402-2409.

Cayré P., Farrugio H., 1996, Reproduction biology of the skipjack (Katsuwonus pelamis) in the Atlantic Ocean. In: Symons P.E.K, Miyake P.M., Sakagawa G.T. (Eds.) The international skipjack year programme ICCAT, Madrid, pp. 252-272.

Corriero A., Desantis S., Deflorio M., Acone F., Bridges C.R., De la Serna J.M., Megalofonou P., De Metrio G., 2003, Histological investigation on the ovarian cycle of the bluefin tuna in the western and central Mediterranean. J. Fish Biol. 63, 108-119.

Dawson W.A., 1986, Change in western mackerel (Scomber scombrus) spawning stock composition during the spawning season, J. Mar. Biol. Assoc. UK 66, 367-383.

De la Serna, J.M., Ortiz de Urbina, J.M., Macias D. 1996, Observations on sex ratio, maturity and fecundity by length-class for swordfish (Xiphias gladius) captured with surface longline in the Western Mediterranean. Int. Comm. Conserv. Atl. Tunas, Coll. Vol. Sci. Pap. 45, 115-139.

DeMartini E.E., Uchiyama J.H., Williams H.A., 2000, Sexual maturity, sex ratio, and size composition of swordfish, Xiphias gladius, caught by the Hawaii-based pelagic longline fishery. Fish. Bull. 98, 489-506.

DeMartini E.E., Uchiyama J.H., Humphreys R.L. Jr., Sampaga J.D., Williams H.A., 2007, Age and growth of swordfish (Xiphias gladius) caught by the Hawaii-based pelagic longline fishery. Fish. Bull. 105, 356-367.

Dewees C.M., 1992, Swordfish. In: Leet W.S., Dewees C.M., Haugen C.M. (Eds.), California's living marine resources and their utilization, California Sea Grant Extension Program, Davis CA, pp. 148-150.

Farley J.H., Davis T.L.O., 1998, Reproductive dynamics of southern bluefin tuna, Thunnus maccoyii. Fish. Bull. 96, 223-236.

Gorbunova N.M., 1969, Breeding grounds and food of the larvae of the swordfish Xiphias gladius Linnee (Pisces, Xiphiidae). Probl. Ichthyol. 9, 375-387.

Hinton M.G., Taylor, R.G., Murphy M.D., 1997, Use of gonad indices to estimate the status of reproductive activity of female swordfish, Xiphias gladius: A validated classification method. Fish. Bull. 95, 80-84.

Hazin F., Hazin H., Boeckmann C., Travassos. P., 2001, La reproduction de l'espadon (Xiphias gladius) dans l'Atlantique sud ouest équatorial : la ponte et la fécondité. Coll. Vol. Sci. Pap. 52, 12331240 . 
Horwood J.W., Bannister R.C.A. Howlett G.J. , 1986, Comparative fecundity of North Sea plaice (Pleuronectes platessa L.) .Proc. R. Soc. London Ser. B, Biol. Sci. 228, 401-431.

Houde E.D., 1989, Comparative growth, mortality and energetics of marine fish larvae: Temperature and implied latitudinal effects. Fish. Bull. 87, 471-495.

Hunter J.R., Macewicz B.J., 1985, Measurement of spawning frequency in multiple spawning fishes. In Lasker R. (Ed.) An egg production method for estimating spawning biomass of pelagic fish: application to the northern anchovy, Engraulis mordax. US Dep. Commerc., NOAATech. Rep. NMFS 36, pp. 79-94.

Hunter J.R., 1985, Preservation of northern anchovy in formaldehyde solution. In: Lasker R.(Ed.) An egg production method for estimating spawning biomass of pelagic fish: Application to the northern anchovy. Engraulis mordax. US Dep. Commerc., NOAA Tech. Rep. NMFS 36, pp. 63-65.

Itano D.G., 2000, The Reproductive biology of yellowfin tuna (Thunnus albacares) in Hawaiian waters and the western tropical Pacific Ocean: Project Summary. SOEST 00-01 JIMAR Contribution 00-328.

Kraus G., Müller A., Trella K., Köster F.W., 2000, Fecundity of Baltic cod: temporal and spatial variation. J. Fish Biol. 56, 1327-1341.

Longhurst A., 2002, "Murphy's Law revisited: longevity as a factor in recruitment to fish populations". Fish. Res. 56, 125-131.

Lowerre-Barbieri S.K., Barbieri L.R., 1993, A new method of oocyte separation and preservation for fish reproduction studies. Fish. Bull. 91, 165-170.

McCarthy J.L., Friedland K.D., Brodziak J., 2008, Enhancement of image-based fecundity methods: Gravimetric sampling at sea and safer sample preservation Fish. Res. 93, 47-53.

Medina A., Abascal F.J., Megina C., García A., 2002, Stereological assessment of the reproductive status of female Atlantic northern bluefin tuna during migration to Mediterranean spawning grounds through the Strait of Gibraltar. J. Fish Biol. 60, 203-217.

Mejuto J., García-Cortés B., Ramos-Cartelle A., 2006, An overview of research activities on swordfish (Xiphias gladius) and the bycatch species, caught by the Spanish longline fleet in the Indian Ocean.IOTC 2006-WPB-11.

Moreno, P.E.B.; Cabellos L.W.G., Eslava N., 2005, Some reproductive aspects of the swordfish, Xiphias gladius of Venezuela oceanic waters. Proc. Gulf Caribb. Fish. Inst. 47, 631-649.

Murua H., Kraus G., Saborido-Rey F., Witthames P.R., Thorsen A., Junquera S., 2003, Procedures to estimate fecundity of marine fish species in relation to their reproductive strategy. J. Northw. Atl. Fish. Sci. 33, 33-54.

Miyabe N., Bayliff W.H., 1987, A review of the Japanese longline fishery for tunas and billfishes in the eastern Pacific Ocean, 19811987. Bull. IATTC, 19.

Neilson J.D., Kearney J.F., Perley P., Sampson H., 1993, Reproductive biology of Atlantic halibut (Hippoglossus hippoglossus) in Canadian waters. Can. J. Fish. Aquat. Sci. 50, 551563.

Nishikawa Y., Honma M., Ueyanagi S.,Kikawa S., 1985, Average distribution of larvae of oceanic species of scombrid fishes, 19561981. Far seas Fish. Res. Lab. Shimizu. S Ser. 12.
Nishikawa Y., Ueyanagi S., 1974, The distribution of the larvae of swordfish Xiphias gladius in the Indian and Pacific Oceans. In: Shomura R.S., Williams F. (Eds.) Proc. Int. Billfish symposium, Kailua-Kona, Hawaï, 9-12 Aug. 1972. Part 2. Review and contributed papers. US Dep. Comm., NOAA Tech Rep., NMFS/ SSRF/675, pp. 261-264.

Palko B.J., Beardsley G.L., Richards W.J., 1981, Synopsis of the biology of the swordfish, Xiphias gladius Linnaeus. FAO Fish. Synop. 127.

Poisson F., 2001, Structuration et mise en place d'une base de données halieutiques spatio-temporelles géoréférencées pour le suivi des pêcheries palangrières dans le sud-ouest de l'océan Indien. In: Poisson F., Taquet M. (coord.) L'espadon : de la recherche à l'exploitation durable. Programme Palangre Réunionnais, Rapp. Ifremer, pp. 9-58.

Poisson F. , Fauvel C., 2009, Reproductive dynamics of swordfish (Xiphias gladius) in the southwestern Indian Ocean (Reunion Island). Part 1: oocyte development, sexual maturity and spawning. Aquat. Living Resour. 22, 45-58.

Schaefer K.M., 1987, Reproductive biology of black skipjack, Euthynnus lineatus, an eastern pacific tuna. IATTC. Bull. 19.

Schaefer K.M., 1996, Spawning time, frequency, and batch fecundity of yellowfin tuna, Thunnus albacares, near Clipperton Atoll in the eastern Pacific Ocean. Fish. Bull. 94, 98-112.

Sedberry G.R., Loefer J.F., 2001, Satellite telemetry tracking of swordfish Xiphias gladius, off the eastern United States. Mar. Biol. 139, 355-360.

Shingu C., Tomlinson P.K., Peterson C.L., 1974, A review of the Japanese longline fishery for tunas and billfishes in the eastern Pacific Ocean, 1967-1970. Inter-Am Trop. Tuna Comm. Bull. 16.

Stéquert B., Ramcharrun B., 1995, Cycle sexuel du listao (Katsuwonus pelamis) de l'ouest de l'océan Indien. Aquat. Living Resour. 9, 235-247.

Takahashi M., Okamura H.,Yokawa K., Okazaki M., 2003, Swimming behaviour and migration of a swordfish recorded by an archival tag. Mar. Freshw. Res. 54, 527-534.

Taylor R.G., Murphy M.D., 1992, Reproductive biology of the swordfish Xiphias gladius in the straits of Florida and adjacent waters. Fish. Bull. 90, 809-816.

Uchiyama J-H., Shomura R-S., 1974, Maturation and fecundity of swordfish, Xiphias gladius, from Hawaiian waters. US Nat. Mar. Fish. Serv., NOAA Tech. Rep. NMFS/SSRF 675, pp. 142-148.

Wang S., Sun C., Yeh S., 2003, Sex ratios and sexual maturity of swordfish (Xiphias gladius L.) in the waters of Taiwan. Zool. Stud. 42, 529-539.

Ware D.M., 1975, Relation between egg size, growth, and natural mortality of larval fish. J. Fish. Res. Board Can. 32, 2503-2512.

Yabe H., Ueyanagi S., Kikawa S., Watanabe H., 1959, Study on the life history of the swordfish (Xiphias gladius) Linnaeus. Rep. Nankai Reg. Fish. Res. Lab. 10, 107-150.

Young J., Drake A., Brickhill M., Farley J., Carter T., 2003, Reproductive dynamics of broadbill swordfish, Xiphias gladius, in the domestic longline fishery off eastern Australia. Mar. Freshw. Res. 54, 315-332. 